\title{
Riparian woodland encroachment following flow regulation: a comparative study of Mediterranean and Boreal streams
}

\author{
M. Dolores Bejarano(1) Á. Sordo-Ward ${ }^{(2)}$ \\ Received January 17, 2011 \\ Revised May 6, 2011 \\ Accepted June 23, 2011
}

ABSTRACT

Key-words:

life-form,

Mediterranean,

Boreal,

flow alteration, vegetation encroachment

\begin{abstract}
Water development accompanying mankind development has turned rivers into endangered ecosystems. Improving the understanding of ecological responses to river management actions is a key issue for assuring sustainable water management. However, few studies have been published where ecological metrics have been quantified in response to various degrees of flow alteration. In this work, changes in natural distribution of trees and shrubs within the riparian corridor (as indicator of the ecological status of the fluvial ecosystem) were quantified at multiple sites along a flow alteration gradient (as indicator of impact) along two regulated river reaches, one Boreal and the other Mediterranean, each downstream of a dam. Based on the obtained relationships we evaluated differences in response trends related to local physico-climatic factors of the two biomes and regarding to differing life-forms. Woody vegetation establishment patterns represented objective indicators of ecological responses to flow alteration. We found different responses between life-forms. Both trees and shrubs migrated downwards to the channel after dam closure, but shrubs were most impacted under higher degrees of flow alteration in terms of lateral movement. In addition, our results show clear longitudinal recovery trends of natural patterns of tree and shrub distribution corresponding to a decrease in intensity of hydrologic alteration in the Boreal river. However, vegetation encroachment persisted along the entire Mediterranean study reach. This may result from a relatively low gradient of decrease of hydrologic alteration with distance from the dam, coupled with other overlapping pressures and the mediating effect of physico-climatic characteristics on vegetation responses.
\end{abstract}

\section{RÉSUMÉ}

Stratégies d'enracinement des ripisylves de rivières régulées : étude comparative de deux cours d'eau, Boréal et Méditerranéen

\footnotetext{
Mots-clés : Méditerranéen, Boréal, débit régulé, perturbation, enracinement végétal, trait de vie
}

La gestion de l'eau par l'homme menace les écosystèmes fluviaux. Une gestion durable de l'eau implique de connaître les réponses des écosystèmes aux différents modes d'aménagement des rivières. Assez peu d'études proposent des évaluations quantitatives écologiques en réponse à des degrés variables de perturbation des débits en rivière. Ce travail présente les modifications naturelles de la distribution de ligneux, strates arborée et arbustive, au sein de corridors ripariens (indicateurs de l'état écologique de l'écosystème fluvial); ces changements sont quantifiés sur différents sites le long de gradients de perturbation des débits (indicateurs de l'impact), ce pour deux rivières régulées, l'une Boréale, l'autre 


\begin{abstract}
Méditerranéenne, à l'aval de barrages. Nous avons évalué les types de réponses à partir de relations observées au sein des deux biomes (Boréal and Méditerranéen) par rapport aux facteurs locaux physiques et climatiques en s'intéressant aux différents traits de vie des ligneux (arbres et arbustes). Les strates arborées et arbustives réagissent de manière équivalente le long d'un gradient longitudinal (effet distance au barrage) ; les arbustes sont plus sensibles, lors des niveaux les plus forts de débits, aux perturbations latérales sur les berges. De plus, nos résultats montrent clairement une restauration, selon un gradient longitudinal, des dynamiques naturelles pour le cours d'eau Boréal. Toutefois l'enracinement des ligneux existe tout au long du secteur d'étude en rivière Méditerranéenne. Ceci correspond sans doute au gradient relativement faible de diminution des perturbations hydrauliques à distance du barrage. Cet effet s'additionne à l'effet des pressions physico-climatiques qui caractérisent les réponses de la végétation Méditerranéenne.
\end{abstract}

\title{
INTRODUCTION
}

Literature documents a wide range of effects of flow regulation on riparian communities. Regarding plant distribution, reduced inter-annual high flows and lower intra-annual average flows have been shown by many authors to trigger a pulse of woody plant establishment on abandoned channel margins and on new non-flooded areas (e.g., point bars and ridge-andswale features), resulting in channel narrowing downstream of dams. However, most studies have been carried out in the western United States and there have been few comparisons with rivers elsewhere in the world. For example, Nadler and Schumm (1981) and DeWine and Cooper (2007) reported channel narrowing in rivers in Colorado (USA) following vegetation establishment on emergent bars after several years of low flows. Johnson et al. (1998) and Friedman et al. $(1996,1998)$ described vegetation shifts on relatively undisturbed areas of the channel bed of braided-type streams downstream from dams in the Great Plains (USA). Merritt and Cooper (2000), Cooper et al. (2003) and Birken and Cooper (2006) found Tamarix invasion on intermediate elevation surfaces in areas where the channel narrowed in the years immediately following closure of Flaming Gorge Dam on the Green river (Colorado and Utah, USA). Shafroth et al. (2002) found denser vegetation, primarily composed of Tamarix, along the regulated Bill Williams river than that along other free-flowing rivers in west-central Arizona. In addition, vegetation shift is usually inferred by examination of tree and shrub coverage on aerial photographs and repeated measurements of channel geometry. This approach provides only coarse information, but few studies measure vegetation encroachment directly on the field.

Hydro-geomorphic processes play a major role in determining woody vegetation distribution along rivers. The patterns of species distributions are distinct characteristics of most riparian ecosystems and are deeply related to lateral channel-floodplain gradients of water availability and hydrogeomorphic disturbances (Johnson and Lowe, 1985; Malanson, 1993; Tabacchi et al., 1996; Bendix, 1998; Patten, 1998; Corenblit et al., 2007). Different tolerance to water stress or submergence and to scour or burial, leads riparian trees and shrubs to colonize specific fluvial landforms (Hupp and Osterkamp, 1996; Hupp and Rinaldi, 2009). Patterns of woody species distribution and quantitative relationships with flow alterations remain insufficiently understood. Recent studies have pointed to the need of understanding the role of flow alteration in modifying ecological processes to support scientifically defensible guidelines for developing general principles for flow regime management (Acreman, 2005; Arthington et al., 2006; Poff et al., 2006, 2010; Poff and Zimmerman, 2010).

The response of riparian vegetation to river regulation varies among rivers and regions, depends on how and how much the flow regimes are modified, and on the species involved. Consequently, transferring relationships of flow alteration with ecological response among rivers in different regions is a difficult task. The study of the responses of riparian communities to flow changes can be simplified by categorizing species into functional groups (Merritt et al., 2010), i.e., sets of plants showing similar responses to environmental conditions and 
having similar effects on ecosystem processes (Noble and Gitay, 1996; Díaz and Cabido, 1997). The most common and simplest method for classifying plants is by life-form. Plant functional types based on life-forms, e.g., trees, shrubs, grasses and forbs, represent the main aspects of ecosystem function (Aguiar et al., 1996). The life-form approach increases the capacity to detect and synthesize complex flow alteration - riparian ecosystem response relationships. In addition, comparative studies which use standardized metrics of vegetation shifts along rivers in different regions help reach general conclusions about vegetation behavior in regulated systems. This allows sharing restoration strategies and sustainable river management actions across frontiers.

In this paper, we generate empirical response curves relating flow alteration to the changes of tree and shrub establishment patterns for two dammed rivers in two different biomes, Boreal and Mediterranean. We specifically address the following questions: (1) do vegetation responses to flow alteration vary between trees and shrubs (i.e., between the woody lifeforms)? (2) are their responses similar in a Boreal and a Mediterranean stream (i.e., between two different biomes)?

\section{MATERIALS AND METHODS}

\section{> STUDY SITES}

In this study we selected two representative rivers of Boreal and Mediterranean biomes: the Vojmån and Tiétar rivers, respectively (Figure 1). The Vojmån is a $225 \mathrm{~km}$ long tributary of the Ångermanälven river in southern Lapland (Västerbotten province, Sweden). It originates on the mountain Kittelfjäll at $1100 \mathrm{~m}$ a.s.I. on the border between Sweden and Norway and ends in Volgsjön Lake at 350 m a.s.I. (Figure 1a; Volgsjön lake is not shown on map). The Vojmsjön dam in the middle-lower part of the river was built in 1948 for hydropower production and the reservoir has a maximum capacity of $594 \times 10^{6} \mathrm{~m}^{3}$. The average annual precipitation is $550 \mathrm{~mm} \cdot \mathrm{y}^{-1}$, represented mostly by snow during autumn and winter, and is distributed homogeneously throughout the years and across the study region. Vojmån historically featured a nival flow regime with a mean daily discharge of $39 \mathrm{~m}^{3} \cdot \mathrm{s}^{-1}$ at the site of the present dam (Figure 2a). We studied the regulated 65-km long reach of Vojmån between the Vojmsjön dam and Volgsjön lake (Figure 1a). This is mainly a single sinuous channel with an even gradient of around $1.7 \mathrm{~m} \cdot \mathrm{km}^{-1}$. Boulders and cobbles are the dominant substrate of most of channel and banks. The native floodplain forest is dominated by Betula pubescens Ehrh., Picea abies (L.) H. Karst and Pinus sylvestris L. Other tree and shrub species are Populus tremula L., Sorbus aucuparia L., Juniperus communis L. and Salix caprea L. Willows, such as S. phylicifolia L. and S. lapponum L., are the most widespread shrubs.

The Tiétar river is a 150-km-long tributary of the Tagus river in central-western Spain (Figure 1b). It originates in the Gredos Mountains at $750 \mathrm{~m}$ a.s.I. and ends into the Torrejón-Tiétar reservoir prior to the confluence of the Tiétar and Tagus rivers (the Torrejón-Tiétar reservoir is not shown in Figure 1b). The Rosarito dam, which was built halfway down the river, became operational in January 1959 and is used for irrigation purposes (Ministerio de Medio Ambiente, 2006). It has an active storage capacity of $85 \times 10^{6} \mathrm{~m}^{3}$. The average annual rainfall exceeds $1000 \mathrm{~mm} \cdot \mathrm{y}^{-1}$ in the mountains, which rarely occurs as snow, and $500 \mathrm{~mm} \cdot \mathrm{y}^{-1}$ in the lower valley. Rain occurs mainly during winter and early spring, while summer is the dry season. Consequently, the Tiétar river exhibits pluvial seasonal flow variability, with winter and spring peak flows (Figure 2b). Rainfall also deeply fluctuates from year to year. Natural mean daily discharge at dam site was $40 \mathrm{~m}^{3} \cdot \mathrm{s}^{-1}$. This study focuses on the $62-\mathrm{km}$ regulated reach of the Tiétar downstream from the Rosarito dam (Figure 1b). The floodplain is intensively used for agriculture and is characterized by numerous settlements. The selected river reach is a wandering to meandering channel that flows through an unconfined valley (according to Rosgen, 1996). It has a coarser substrate and steeper channel bed along its first few kilometers and progressively becomes a low-gradient sand bed river downstream. Its native 


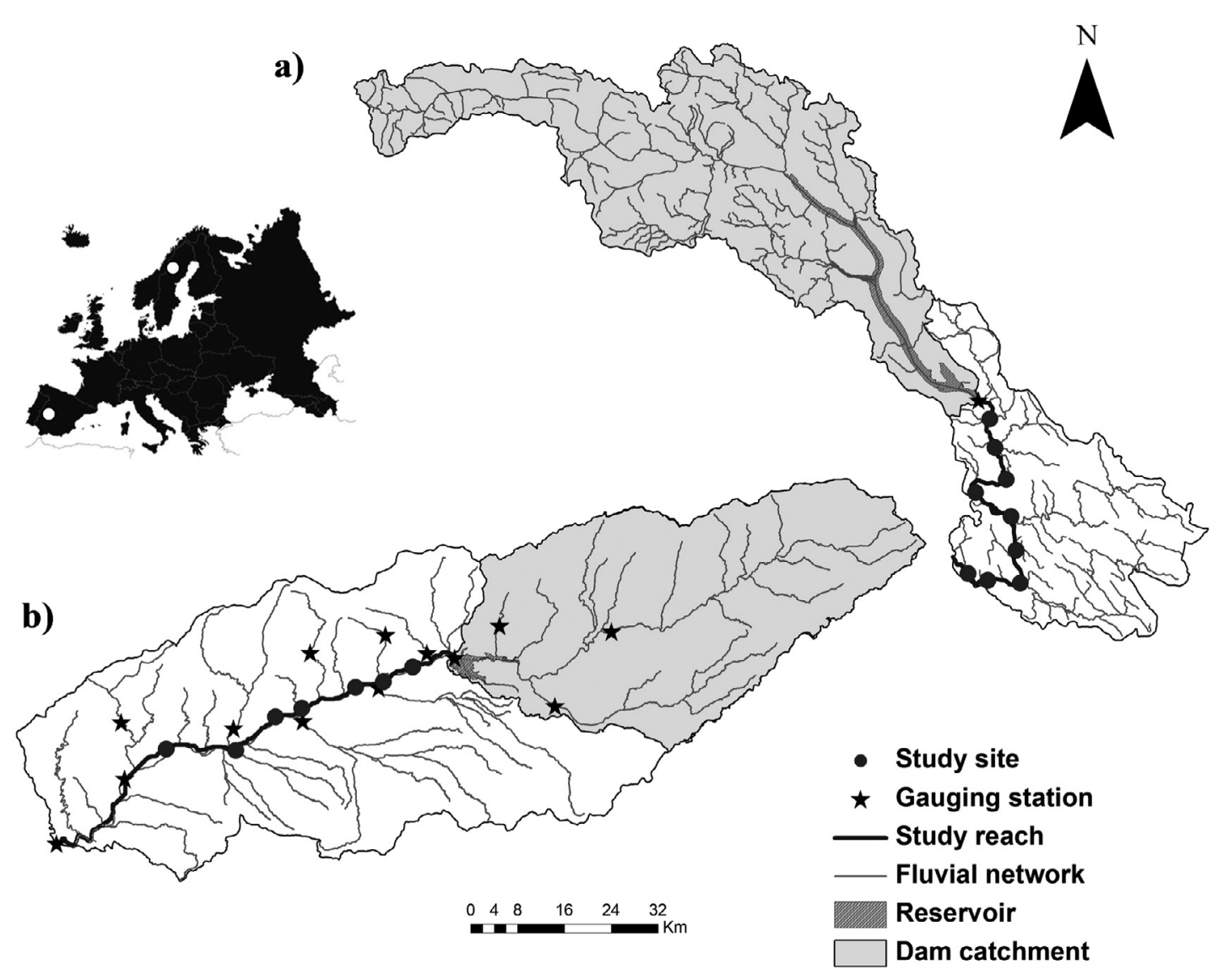

Figure 1

The Vojmån river basin in northern Sweden (Boreal biome; (a) and the Tiétar river basin in central-western Spain (Mediterranean biome; (b) maps show river network and location of gauging stations, the Vojmsjön and Rosarito reservoirs and surveyed river sites. The artificial Volgsjön lake and the Torrejón-Tiétar reservoir are located at the end of the Vojmån and Tiétar rivers, respectively, but they are not shown on maps.

\section{Figure 1}

La rivière Vojmån au Nord de la Suède (biome Boréal ; (a) et la rivière Tiétar au centre ouest de l'Espagne (biome Mediterranéen; (b) les cartes montrent les réseaux fluviaux et les stations limnométriques à l'aval des barrages de Vojmsjön et Rosarito et les sites d'étude.

floodplain forest is dominated by Alnus glutinosa (L.) Gaertn. (black alder), Fraxinus angustifolia Vahl. (narrow-leaf ash) and Salix salviifolia Brot. (sage-leaf willow). Other species in the area are Celtis australis (L.) (Mediterranean hackberry) and Flueggea tinctoria (L.) G.L. Webster (Ibero-African shrubby spurge, Spanish common name "tamujo"), which appears only at certain locations. A comparative summary of the main characteristics of the two rivers is presented in Table I.

\section{> HYDROLOGIC AND FIELD DATA ANALYSIS}

We characterized the natural and altered flow regimes along the two study reaches. For the Vojmån river, mean daily discharge data at Vojmsjön dam site (Figure 1a; gauge 20031 ; discharge series 50033; provided by the Swedish Meteorological and Hydrological Institute) were used to characterize hydrologic changes over a continuous time record starting in 1909. 1909-1947 was considered as the natural period (i.e., pre-impact), while 1948-2008 as the 


\section{a)}

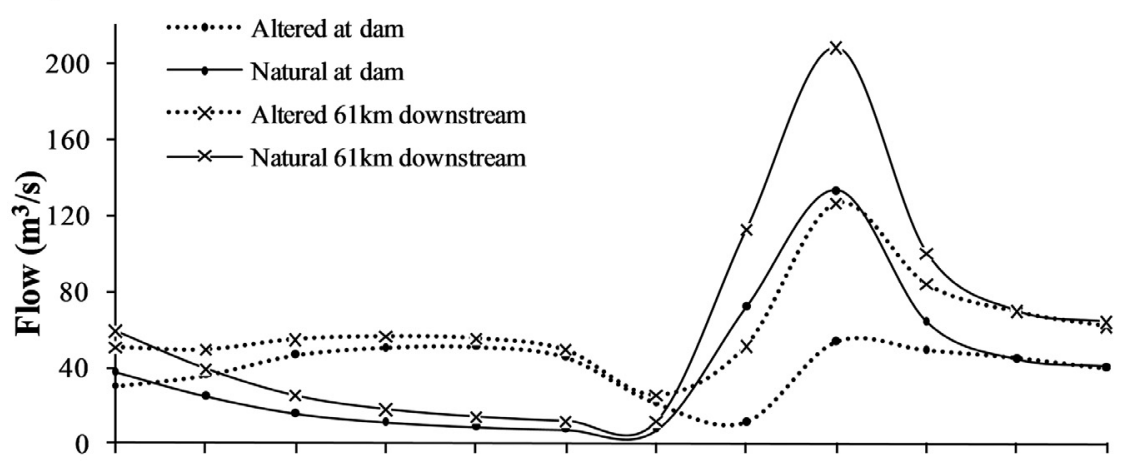

Jan Feb Mar Apr May Jun Jul Aug Sep Oct Nov Dec

b)

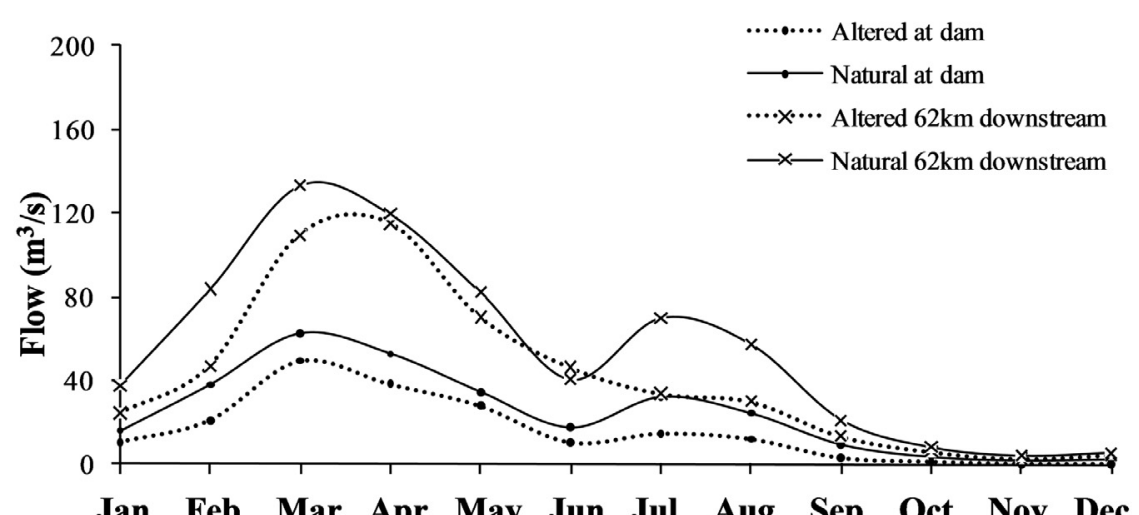

Figure 2

Intra-annual flow fluctuations at the Vojmsjön and Rosarito dams sites (dots) and 61-62 km downstream (crosses) for the Vojmån (a) and Tiétar (b) regulated reaches. Lines represent the free-flowing mean monthly flow (solid lines) and the altered mean monthly flow (dashed lines).

\section{Figure 2}

Variations interannuelles des débits à l'aval immédiat des barrages de Vojmsjön et Rosarito (ronds) et 61-62 km à l'aval (croix) pour les secteurs régulés de la Vojmån (a) et de la Tiétar (b). Les lignes continues représentent les débits naturels et les lignes pointillées les débits régulés (en moyennes mensuelles).

altered period (i.e., post-impact). In the Vojmån river, we calculated the total natural and altered annual runoff along the study reach downstream from the dam as a proportion of the upstream drainage area, based on the information from the gauge at the dam site (i.e., 19091948 for natural runoff and 1949-2008 for altered runoff). The natural mean monthly flow along the reach downstream was calculated proportionally to the natural mean monthly flow recorded at the dam site gauge (1909-1948). The altered mean monthly flow downstream from the dam was calculated by summing the mean monthly flow of the mainstem and the mean monthly flow from the tributaries. The mean monthly flow of the mainstem downstream from the dam was considered proportional to the altered mean monthly flow recorded at the dam site gauge (1949-2008), whereas, because there was no gauge available at tributaries, we assumed that tributaries hydrograph had the same annual distribution as the natural hydrograph at dam (1909-1948).

For the Tiétar river, we used gauged-altered and reconstructed-natural flow data for a fifteen year period (flow series from 1985 to 2000). The altered daily flow data were recorded from a gauging station on the Tiétar river at the Rosarito dam (gauge 3127), from a station located $62 \mathrm{~km}$ downstream of the dam (gauge 3184), and from several gauging stations on the 


\section{Table I}

Characteristics of the Vojmån and Tiétar rivers and respective study reaches downstream of the Vojmsjön and Rosarito dams.

\section{Tableau I}

Caractéristiques des rivières Vojmån (Suède) et Tiétar (Espagne) et de leurs secteurs respectifs d'étude à l'aval des barrages Vojmsjön et Rosarito.

\begin{tabular}{|c|c|c|}
\hline & Tiétar River & Vojmån River \\
\hline \multicolumn{3}{|l|}{ General description } \\
\hline Location & Central-western Spain & Southern Lapland, Sweden \\
\hline Biome & Mediterranean & Boreal \\
\hline Basin area $\left(\mathrm{km}^{2}\right)$ & 4478 & 3543 \\
\hline Land use & $\begin{array}{l}\text { Agriculture, urban settlements, cat- } \\
\text { tle, gravel mining }\end{array}$ & $\begin{array}{l}\text { Natural forest, timber produc- } \\
\text { tion, hay making }\end{array}$ \\
\hline Study reach length $(\mathrm{km})$ & 62 & 65 \\
\hline Number of study sites & 7 & 9 \\
\hline \multicolumn{3}{|l|}{ Dam description } \\
\hline Name & Rosarito & Vojmsjön \\
\hline Dam closure (y) & 1959 & 1948 \\
\hline Reservoir volumen $\left(\mathrm{m}^{3}\right)$ & $85 \times 10^{6}$ & $594 \times 10^{6}$ \\
\hline Dam watershed $\left(\mathrm{km}^{2}\right)$ & 1736 & 2253 \\
\hline Dam main use & Irrigation & Hydropower \\
\hline \multicolumn{3}{|l|}{ Hydrology } \\
\hline Flow regime & Pluvial (Winter and spring peaks) & Nival (spring peak) \\
\hline $\begin{array}{l}\text { Mean annual rainfall (mm. } \\
\mathrm{y}^{-1} \text { ) }\end{array}$ & $\begin{array}{l}\text { Mountain range: } 1000 \\
\text { Valley: } 500\end{array}$ & 550 (snow -fall and winter-) \\
\hline $\begin{array}{l}\text { Mean natural annual runoff } \\
\text { at dam }\left(\mathrm{m}^{3} \cdot \mathrm{y}^{-1}\right)\end{array}$ & $766 \times 10^{6}$ & $1245 \times 10^{6}$ \\
\hline $\begin{array}{l}\text { Mean altered annual runoff } \\
\text { at dam }\left(\mathrm{m}^{3} \cdot \mathrm{y}^{-1}\right)\end{array}$ & $485 \times 10^{6}$ & $1214 \times 10^{6}$ \\
\hline \multicolumn{3}{|c|}{ Geomorphology \& vegetation } \\
\hline River morphology & Wandering to meandering & Single sinuous channel \\
\hline Dominant grain size class & $\begin{array}{l}\text { Upper sites: cobbles, boulders } \\
\text { Lower sites: sand }\end{array}$ & Cobbles, boulders \\
\hline Mean channel slope $(\mathrm{m} / \mathrm{km})$ & $\begin{array}{l}\text { Upper sites: } 2.37 \\
\text { Lower sites: } 0.57\end{array}$ & 1.7 \\
\hline Valley description & Unconfined & Semi-confined \\
\hline $\begin{array}{l}\text { Common native floodplain } \\
\text { species }\end{array}$ & $\begin{array}{l}\text { Trees: Alnus glutinosa, Fraxinus an- } \\
\text { gustifolia, Celtis australis } \\
\text { Shrubs: Salix salviifolia, Flueggea } \\
\text { tinctoria }\end{array}$ & $\begin{array}{l}\text { Trees: Pinus sylvestris, Picea } \\
\text { abies, Betula pubescens } \\
\text { Shrubs: Salix caprea, S. phyli- } \\
\text { cifolia, S. lapponum }\end{array}$ \\
\hline
\end{tabular}
Ministry of Environment and Public Works, Cedex; http://cedex.es). Because pre-dam flow series were not available, natural mean monthly discharge data came from the Sacramento reconstructed series provided by the Tagus water authority for the dam site and the upstream Torrejón-Tiétar reservoir. In the Tiétar river, for the altered total annual runoff calculations along the reach downstream from the dam, we added the Tiétar river baseflow to runoff contributions from its tributaries using information from their gauging stations. For ungauged tributaries, we extrapolated the runoff values from a fitted regression to the gauged data. Direct pumping along the study reach was also incorporated according to the information provided by the Tagus Water Authority (i.e., $122 \times 10^{6} \mathrm{~m}^{3} \cdot \mathrm{y}^{-1}$ for irrigation, and $10 \times 10^{6} \mathrm{~m}^{3} \cdot \mathrm{y}^{-1}$ 11 for water supplies). The mean monthly flow along the reach was determined from the flow 
data which was simulated (i.e., natural) and recorded (i.e., altered) at the gauge at the dam site and at the gauge located $62 \mathrm{~km}$ downstream from the dam (1985-2000). First, we calculated the mean monthly flow at both gauge sites and then we calculated the mean monthly flow along the reach between the gauges by weighting both distributions proportionally to the distance to their respective locations.

To quantify hydrologic impact of the dams along the reach downstream, we calculated the hydrologic alteration for both rivers as the ratio between the mean spring peak flow of the regulated and natural flow series. Spring was chosen because it is the season where effects of regulation are most visible throughout the year. One minus such ratio was termed as spring peak flow attenuation index (SPFA):

$$
S P F A=1-\frac{\overline{s p f}_{\text {altered }}}{\overline{s p f}_{\text {natural }}} .
$$

Field surveys were carried out along 300 to 2000-m long sites homogeneously distributed along the two regulated reaches downstream of the dams (Figure 1). Nine sites were surveyed for Vojmån, and seven for Tiétar. At each site, surveys were carried out along 30-m wide transects perpendicular to the main channel. Number of transects per site ranged between 4 and 11 ; they were evenly spaced along homogeneous sites, but were placed at specific locations to ensure a proper characterization of heterogeneous sites. The more heterogeneous the river, the longer the sites and the higher the number of transects used for the characterization. We were interested in the lateral extent and nature of the vegetation along the gradient from the channel to the terrace top or hillslope. We identified consecutive and partly overlapping zones of homogeneous woody vegetation within each transect. Zones were classified according to their dominant woody life-form (i.e., trees and shrubs) and to their time of establishment (i.e., pre-dam if vegetation established before the dam was built, and post-dam if vegetation established after damming). We used field evidence along with pre-dam aerial photographs (i.e., 1947 and 1956 aerial photographs for the Vojmån and Tiétar rivers, respectively) to distinguish between pre-dam and post-dam vegetation (See Bejarano et al., 2011 for a fuller explanation of vegetation zones identification). For each vegetation zone we measured the distance to the water's edge and the height above summer water-level from the lowest limit of each vegetation zone. In addition, we described the physical characteristics of each site. Field surveys were carried out in July and August 2008 for the Tiétar river and in August 2009 for the Vojmån river. Measurements were made by using a Suunto level, a measuring tape and a laser distance measuring tool.

We compared the pre and post dam establishment locations of trees and shrubs within each study site along the two rivers using two independent one-way ANOVA tests for distance from and height above water-level of the identified vegetation zones. In addition, we calculated the ratio between the post-dam and pre-dam locations of trees and shrubs as standardized indices of plant distribution changes after damming. The resulting values were: distance recovery index (DRI) and height recovery index (HRI), as the distance from or height above the water level of vegetation established after the dam divided by distance or height of vegetation established before the dam, respectively. We used the term "recovery" to refer to the return to the pre-regulation conditions (see Bejarano et al., 2011 for further explanation). Thus, indices $<1$ indicate an impact of regulation and vegetation encroachment downwards to the main channel. The longitudinal trends of change in lateral distance and height were analysed through a simple regression of all DRI and HRI values per site with hydrologic alteration as the independent variable in the two studied rivers.

\section{RESULTS}

\section{> HYDROLOGIC ALTERATION}

In the Vojmån river, the mean annual runoff was almost identical between the free-flowing (1909-1947) and regulated (1948-2008) periods. At the dam site, free-flowing and regulated 


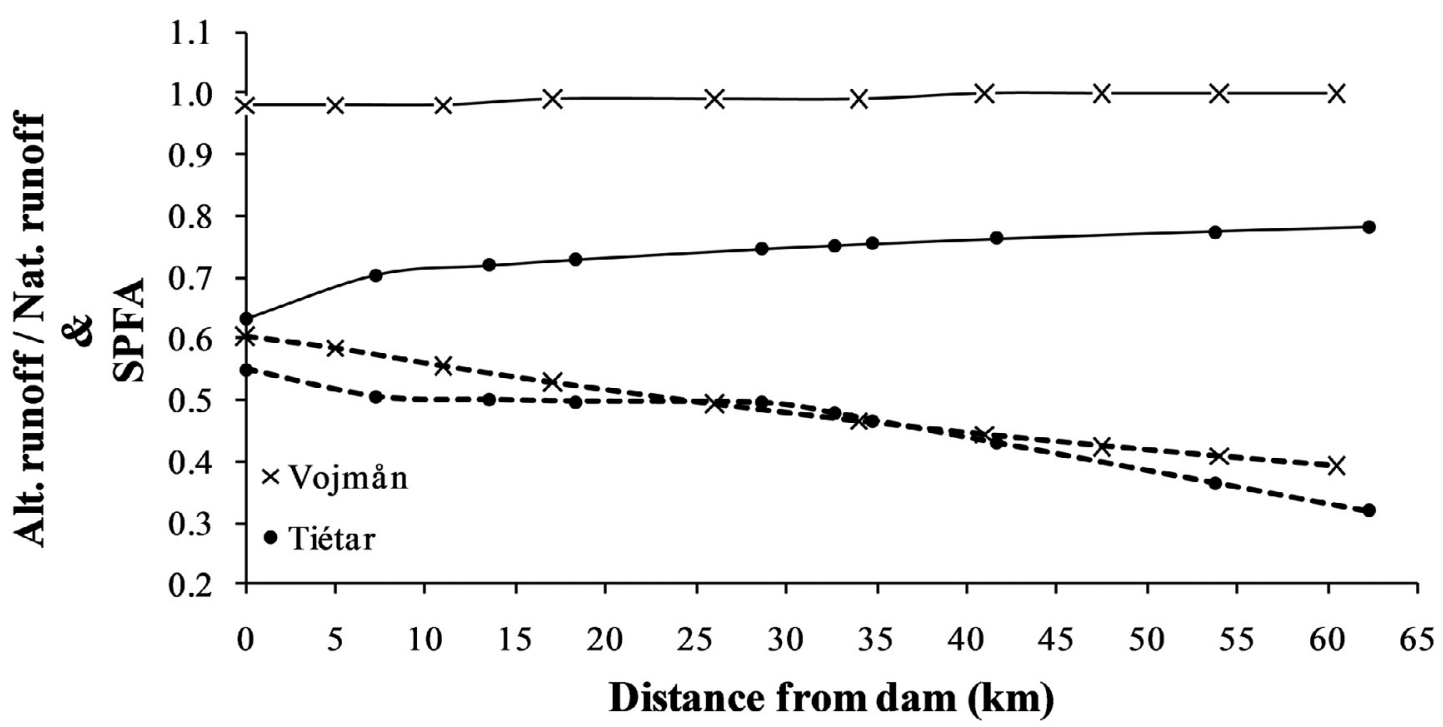

\section{Figure 3}

Gradient of the mean annual runoff alteration (solid lines) and the spring peak flow attenuation (dashed lines) along the Vojmån (crosses) and Tiétar (dots) study reaches downstream of the Vojmsjön and Rosarito dams. The former is measured as the ratio between the altered and the natural mean annual runoffs at each surveyed site. The latter is measured as one minus the quotient between the altered and natural mean spring peak flows (SPFA; see methods for a fuller explanation).

\section{Figure 3}

Gradient de la moyenne annuelle des débits perturbés (lignes continues) et des pics de débits printaniers régulés (lignes pointillées) tout au long de la rivière Vojmån (croix) et de la rivière Tiétar (ronds) à l'aval des barrages de Vojmsjön et Rosarito. Le premier est mesuré comme étant le rapport entre le débit annuel moyen perturbé sur le débit annuel moyen naturel pour chaque site d'étude. Le second est calculé selon la formule : un moins le quotient entre les pics de débits printaniers régulés et les pics de débits printaniers naturels (SFFA : voir section Méthodologie pour plus d'information).

annual runoff measured $1246 \times 10^{6} \mathrm{~m}^{3} \cdot \mathrm{y}^{-1}$ and $1225 \times 10^{6} \mathrm{~m}^{3} \cdot \mathrm{y}^{-1}$, respectively for the two time periods; while they both measured $1660 \times 10^{6} \mathrm{~m}^{3} \cdot \mathrm{y}^{-1}$ at the end of the study (i.e., impacted) reach. Thus, the ratio between the altered and natural mean annual runoff was near one along the entire regulated reach (Figure 3 ). On the other hand, the annual runoff in the Tiétar river at the dam site decreased from 766 to $485 \times 10^{6} \mathrm{~m}^{3} \cdot \mathrm{y}^{-1}$ between 1985 and 2000 according to the reconstructed and recorded flow, respectively. This represents a reduction of $37 \%$ annual runoff. For the Tiétar river the ratio between the altered and natural mean annual runoff increased progressively along the 62-km study area, from 0.64 to 0.78 (Figure 3).

The flow fluctuation throughout the year decreased for the Vojman river and the nival freeflowing regime disappeared after damming (Figure 2a). Flow stabilized around the average (Figure 2a). Downstream from the dam, the spring peak flow attenuation index decreased from 0.60 at the dam site to $0.3961 \mathrm{~km}$ downstream (Figure 3). Unlike the Vojmån river, in the Tiétar river the pluvial intra-annual flow fluctuation remained after damming (Figure 2b). The highest flows still occurred during winter and spring and a summer dry period persisted; however, the magnitudes of flows were considerably reduced in all cases (Figure 2b). Downstream from the dam, the SPFA decreased from 0.55 at the dam site to $0.3262 \mathrm{~km}$ downstream from the dam (Figure 3).

\section{> CHANGES IN VEGETATION ESTABLISHMENT PATTERNS}

tions relative to the wetted channel decreased significantly during the post-dam period along 
the whole reach, as shown by ANOVA (Figure 4). Thus, the riparian woodland encroached downwards to the channel. While trees migrated downwards to the channel more than shrubs for the Vojmån river, the Tiétar river showed the opposite trend. In all cases, trees grew on surfaces that were farther from the water's edge and higher elevation surfaces, and shrubs grew on surfaces that were closer to the water's edge and at lower elevation. For the Boreal river, comparing to the pre-regulation positions, trees grew on surfaces that were, on average, $3.8 \mathrm{~m}$ closer to the summer wetted-channel after regulation (57\% establishment distance reduction after regulation), while shrubs grew $1 \mathrm{~m}$ closer (38\% distance reduction after regulation; Figure 4). On the other hand, trees occurred on surfaces at an elevation, on average, $0.4 \mathrm{~m}$ closer to the elevation of the alluvial water table in summer (58\% establishment height reduction after damming), and shrubs $0.2 \mathrm{~m}$ closer (38\% height reduction; Figure 4). For the Mediterranean river, compared to the pre-dam positions, trees occurred on surfaces that were, on average, $3.0 \mathrm{~m}$ closer to the water's edge (48\% establishment distance reduction after regulation), whereas shrubs grew $2.1 \mathrm{~m}$ closer (77\% distance reduction). On the other hand, trees occurred on surfaces at an elevation, on average, $1.8 \mathrm{~m}$ closer to the elevation of the water surface (73\% establishment height reduction), whereas shrubs grew at an elevation $1.0 \mathrm{~m}$ closer ( $90 \%$ height reduction; Figure 4$)$ after dam closure.

The DRI and $\mathrm{HRI}$ values varied between 0 and 1 , indicating vegetation encroachment downwards to the main channel along the two regulated reaches after regulation (Figure 5). Values $>1$ were not found, which reflects no vegetation recession. For the Vojmån river the lowest $\mathrm{ERI}$ and DRI values occurred close to the dam and values approached one with increasing distance from the dam and as hydrologic alteration decreased. HRI-SPFA regressions showed higher $r^{2}$ than DRI-SPFA regressions (i.e., HRI-SPFA: $r^{2}=0.56$ for trees and shrubs; and DRI-SPFA: $r^{2}=0.13$ for trees and $r^{2}=0.37$ for shrubs; $P<0.05$ in all cases). On the contrary, there were no clear longitudinal trends for $\mathrm{HRI}$ and $\mathrm{DRI}$ values for the Tiétar river (i.e., mean and standard deviation for HRI values: $0.62+/-0.1$ for trees and $0.58+/-0.17$ for shrubs). There were no relationships between establishment changes and hydrologic alteration for the Mediterranean river (i.e., HRI-SPFA: $r^{2}=0.01$ for trees and $r^{2}=0.06$ for shrubs; and DRI-SPFA: $r^{2}=0.19$ for trees and $r^{2}=0.1$ for shrubs; $P>0.05$ in all cases; Figure 5 ).

\section{DISCUSSION AND CONCLUSIONS}

\section{> PATTERNS OF VEGETATION ENCROACHMENT}

This work highlights the role of hydrology in controlling woody riparian plant establishment in rivers located in different regions. Our results suggest that indices based on changes in the lateral distribution of plants are appropriate indicators of hydrologic alteration. The Vojmsjön reservoir dramatically attenuates the floods due to spring snowmelt. The Tiétar river experiences the highest flow decrease in spring as well, coinciding with the filling of Rosarito reservoir, and in addition irrigation withdrawals cause a general decrease in the annual runoff. Consequently, bare fluvial forms suitable for plant recruitment have emerged, where the likelihood of seedling mortality from erosion and prolonged inundation due to floods is rare, especially along the Boreal stream. This situation, coupled with the high soil moisture after winter and the warm temperature and longer daylight of spring and summer - the active growth seasons - triggers recruitment of bottomland riparian woodlands and explains the significant decrease of the establishment distance and height from the channel of woody riparian species compared to their locations in pre-regulation conditions along the two fluvial systems. The vegetation encroachment following flow regulation that we recorded in both regulated Boreal and Mediterranean streams has been also described in other world regions, most of them in semi-arid rivers of the western United States (Johnson et al., 1995; Scott et al., 1996, 1997; Friedman et al., 1996, 1998; Johnson, 2000; Merritt and Cooper, 2000; Shafroth et al., 2002; Cooper et al., 2003; Birken and Cooper, 2006; DeWine and Cooper, 2007).

Riparian woodland development along the Vojmån and Tiétar rivers after damming might have occurred as follows: first, vegetation establishment on bare channel margins, bars and 
a)

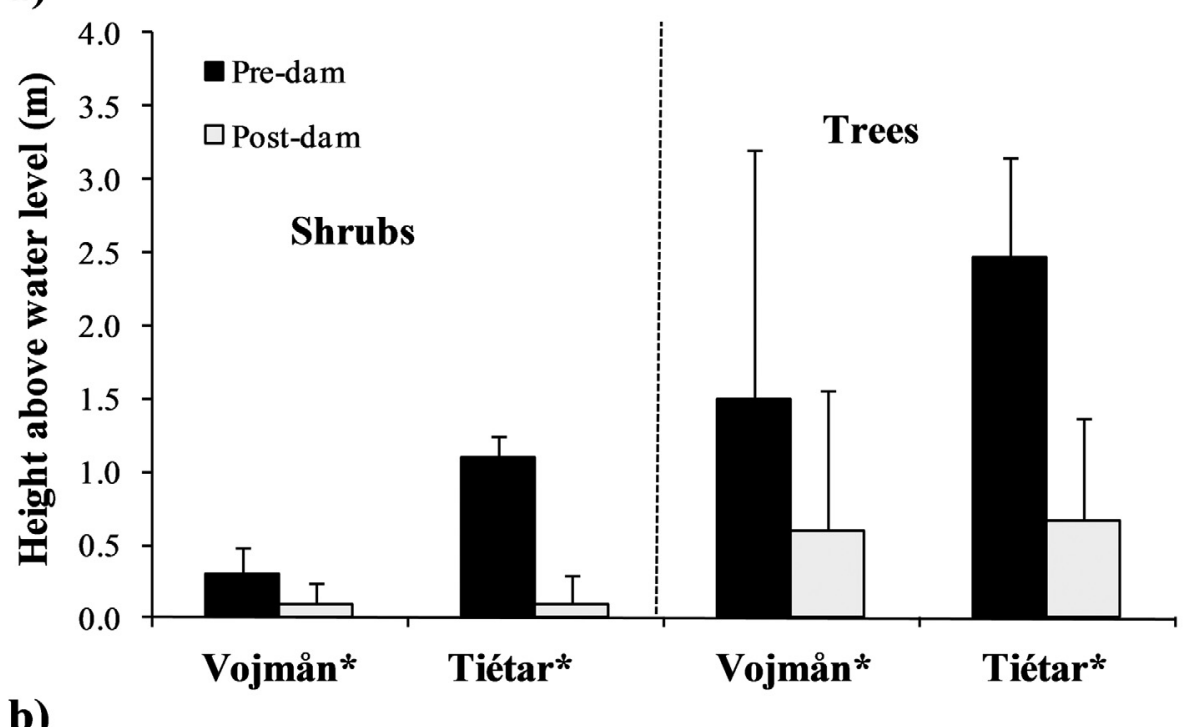

b)

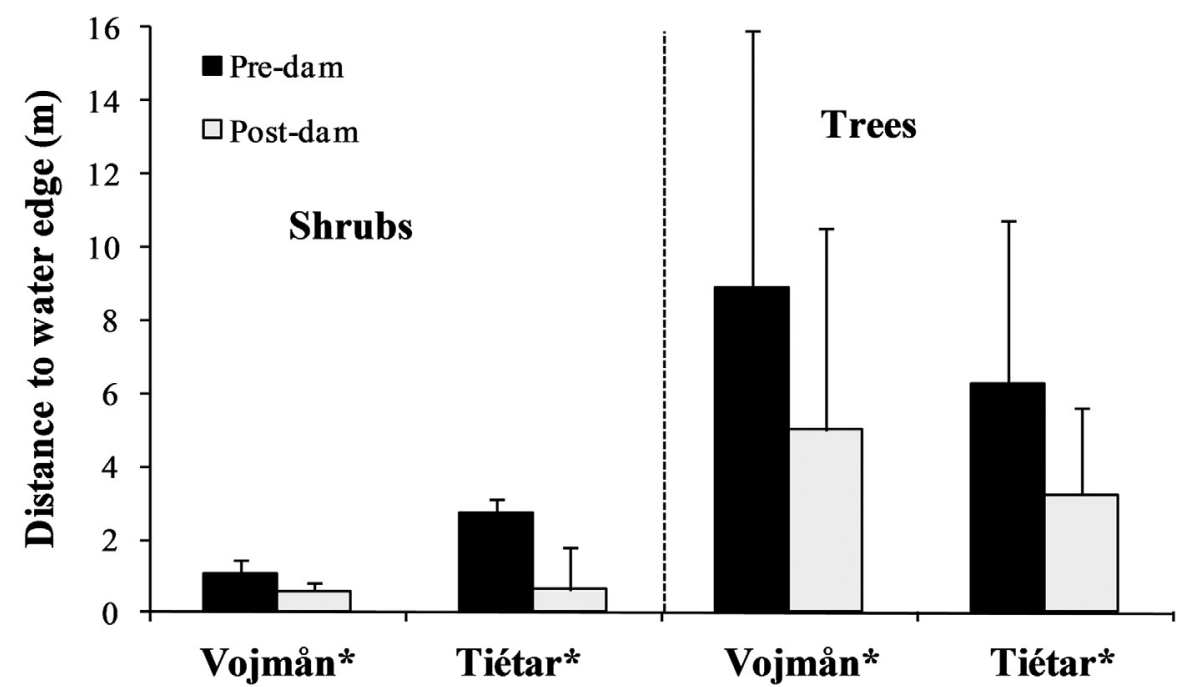

\section{Figure 4}

Mean +/- standard deviation of establishment height above the water-level (a) and distance to the water edge (b) for trees and shrubs along the entire regulated reaches of the Vojmån and Tiétar rives. Black bars represent the pre-dam established vegetation, while white bars represent the post-dam established vegetation. Asterisks represent significant differences between pre- and post-dam locations $(P<0.05)$.

\section{Figure 4}

Moyennes +/- erreur standard des hauteurs établies au dessus du niveau d'eau (a) et distance à la limite de l'eau (b) pour les arbres et arbustes tout au long des secteurs régulés des rivières Vojmån et Tiétar. La végétation amont du barrage est représentée par des traits noirs, celle de l'aval par des barres blanches. Les astérisques montrent des différences significatives amont/aval au seuil de $P<0,05$.

islands, and then, subsequent vertical accretion as well as lateral expansion of these stabilized floodplain landforms over the six decades after the dam closure resulting in a progressive channel narrowing (Turner and Karpiscak, 1980; Williams and Wolman, 1984; Shafroth 4 et al., 2002; Cooper et al., 2003; DeWine and Cooper, 2007). In the Tiétar river, especially along the lowland sites where river energy decreases and islands, sandbars and secondary channels appear, it seems that shrubs tended to colonize islands and in-channel bars and triggered sediment accretion causing such fluvial forms to enlarge and eventually attach to 8 the adjacent historic channel banks. On the other hand, along the high energy boulder-bed 

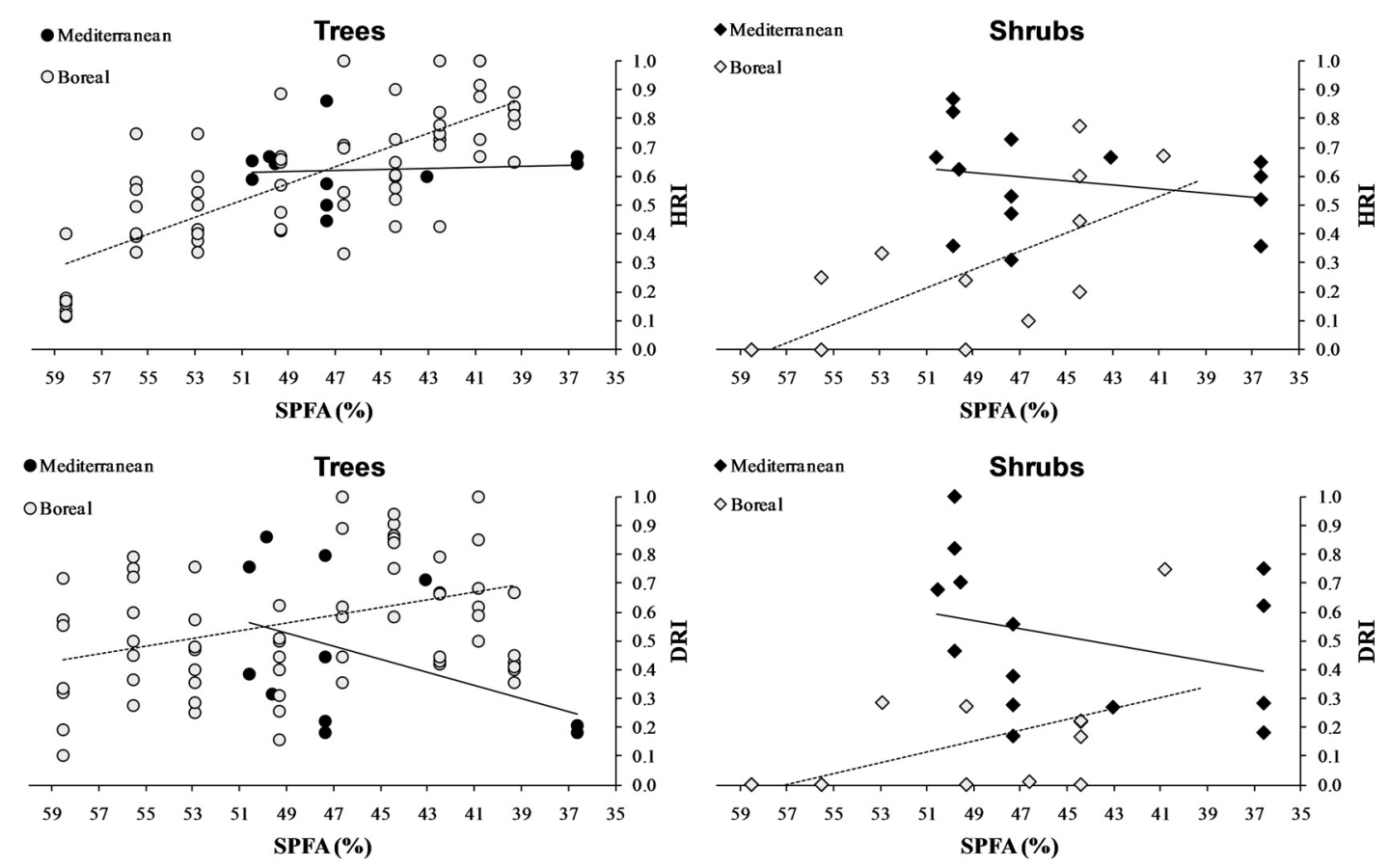

\section{Figure 5}

Height recovery index (HRI) and distance recovery index (DRI) for trees and shrubs against spring peak flow attenuation index (SPFA) for the Vojmån (Boreal; empty symbols) and Tiétar (Mediterranean; filled symbols) rivers. Circles represent trees and diamonds shrubs. Dashed and solid tendency lines represent the relationship between establishment indices and hydrologic alteration index for the Vojmån and Tiétar rivers, respectively.

\section{Figure 5}

Indice de restauration de hauteur (HRI) et indice de restauration de distance (DRI) pour les arbres et les arbustes en fonction de l'indice d'atténuation des pics de débit printaniers (SPFA : voir section Méthodologies) pour la rivière Vojmån (Boréale; symboles vides) et la rivière Tiétar (Méditerranéenne; symboles pleins). Les cercles représentent les arbres et les carrés les arbustes. Les lignes pointillées et continues représentent, respectivement pour les rivières Vojmån et Tiétar, les relations entre les indices d'installation de la végétation et les indices d'altérations hydrauliques.

wandering Vojmån river, it appears that both trees and shrubs tended to expand mainly along the former emerged channel margins and floodplain surfaces developed towards the active channel. The former pathway was similar to the one described by Birken and Cooper (2006) for tamarisk expansion, and the latter was analogous to the process documented by Allred and Schmidt (1999), both at different locations along the Green river (Utah, USA).

\section{> LIFE-FORMS WIDESPREAD}

Contrary to what happened in the Vojmån river, where trees migrated more than shrubs downwards to the channel, in the Tiétar river most of the bare islands and bars were successfully colonized by shrub forms. This widespread proliferation of shrubs after damming in the Tiétar may be partly attributed to the particular characteristics of the Mediterranean climate. The great variability of intensity and frequency of floods from year to year depending on the frequency and intensity of rainfall, and the strong seasonality in flooding associated to seasonal rainfall, clearly distinguish Mediterranean rivers and streams (Resh et al., 1990; Davies et al., 1994; Sabater et al., 1995). Rosarito is a relatively small reservoir and high-return period floods reach occasionally the reach downstream of the dam. Shrubs are pioneers with the ability to colonize floodplains under fluctuating hydrologic conditions occupying what was previously a 
vacant ecological niche. In addition, most of the Tiétar shrub species (i.e., willows and tamujos - F. tinctoria -) have flood-trained growth forms with thick stem and root systems that resist the hydraulic stresses of floods and most of them have re-sprouting capacity (Gasith and Resh 1999; Aguiar and Ferreira, 2005; Prada and Arizpe, 2008; Hughes et al., 2009; www.plants.usda.gov). Among these shrub species, only non-obligate phreatophytes (i.e., $F$. tinctoria) will potentially survive to episodic or seasonal drought when flows become too low to sustain seedlings growth, particularly pronounced immediately below the dam and where there are no aquifer feedings (www.aguas.igme.es, Instituto Geológico y Minero de España). On the contrary, post-regulation conditions do not appear to be conducive to extensive shrubland in the Vojmån river. Unlike in the Mediterranean, rainfall in the Vojmån basin hardly varies from year to year. This, along with a large reservoir, results in the absence of major floods downstream from the dam, which results in late-successional vegetation stages to grow more closely to the edge of the channel. In addition, increased flow levels during winter and ice formation over a large area may affect survival of shrubs saplings more than they affect young trees since the colonization areas for shrubs are typically closer to the active channel (Nilsson, 1999).

\section{> PLANT ESTABLISHMENT CHANGES AND FLOW ALTERATION}

Water needs for irrigation in the Mediterranean river are met by water abstraction at the Rosarito dam and at multiple pumping stations along the reach. Both cause a considerable stream-water table decline which forces plants to establish downward onto lower elevation surfaces within the whole riparian area and floodplain in order to increase their water access. On the other hand, occasional floods during particularly rainy years transform the landforms which are minimally stabilized and closer to the active channel, thus limiting the colonization of these surfaces and causing the observed smaller decrease of plant establishment distance from the channel in the Tiétar river. On the contrary, the degree to which trees and shrubs advanced laterally towards the channel and to lower elevations was of equal proportion for both life-forms in the Vojmån river. The lateral spread of vegetation results from the absence of floods in this river after regulation, whereas the decline of establishment surface level is reflecting the recorded decline of stream-water levels.

Only the Boreal river had a downstream change in trees and shrubs establishment towards the pre-dam locations. This downstream trend corresponds to a decrease of the degree of flow alteration with distance and as large tributaries flow into the main river, concomitant with the absence of other disturbance and with a relatively homogeneous geomorphology (Bejarano et al., 2011). In general, for woody vegetation in the Vojmån river, the highest impact on the plant establishment patterns occurred after a halving of the spring flow where the DRI and HRI were $<0.55$ for trees, and they were $<0.25$ for shrubs. However, low $r^{2}$ for hydrologic alteration and DRI or HRI regressions, and no longitudinal trends of DRI and HRI values, indicated that the predictions of impacts on vegetation based solely on the analysis of changes in the main stream flows is not sufficient, and that other factors may be involved and modulate the impact of flow alteration on woody plant establishment patterns. This assumption agrees with other authors who stated that the effects of dams on the areal extent of downstream vegetation vary among rivers reflecting interactions between regulated flows and the fluvial geomorphic setting (Petts, 1979; Williams and Wolman, 1984; Johnson, 1998). In fact, a detailed review of the surveyed sites in both rivers reveals that smallest widespread of vegetation after regulation (i.e., highest $\mathrm{DRI}$ and $\mathrm{HRI}$ values) could be related not only to a small degree of hydrologic alteration but also to specific site characteristics (i.e., values of such indices around one for the steepest and coarsest substrate banks and narrowest sections).

\section{CONCLUSIONS}

Extensive riparian forest and shrubland can develop after the decrease of annual runoff and floods downstream from dams, although vegetation encroachment pathway and channel 
narrowing process vary among rivers. Along regulated reaches, trees and shrubs may progressively colonize islands and in-channel bars in low-energy rivers or may become widespread within river margins in high-energy rivers, resulting in both cases in reduced channel capacity by increasing hydraulic roughness. Our findings also reveal how particular characteristics of flow regime and geomorphic setting may modulate the degree of the expansion of riparian shrub or tree forms. Pioneer shrubland could be specially favored downstream from dams along low-energy streams whose bed material is sand and which are located in more flow-fluctuating and unpredictable environments; although more study cases would be necessary to generalize these conclusions. One of the benefits of this study is to remind us that bottomland riparian vegetation responds differently to flow regulation in different parts of the world. Thus, sharing management and restoration plans between regulated rivers in different world regions is not so straightforward; the effects of hydrologic alterations on riparian ecosystems are highly influenced by the climatic, geomorphic and floristic characteristics of each site.

\section{ACKNOWLEDGEMENTS}

The study has been possible thanks to the María Dolores Bejarano FPU contract (AP20052680) from the Spanish Ministry of Science and Innovation and to the Álvaro Sordo contract (ARCO2008-0050084350) from the Spanish Ministry of Environment. It has been also supported by the funds from the Coordination Action VIAGUA (410AC0399) under the CYTED Program (Iberoamerican Program of Science and Technology for the Development), and from the MOCHCA project (CGL2009-14258) funded by the Spanish Ministry of Science and Innovation. We also thank Jacqueline Betsch for her assistance with language, and Lovisa Lind and Daniel Sisí for their assistance during field surveys. Finally, we are very grateful to Christer Nilsson, Marta Gonzalez del Tánago and Miguel Marchamalo for their comments on the study.

\section{REFERENCES}

Acreman M., 2005. Linking science and decision-making: features and experience from environmental river flow setting. Environ. Modell. Softw., 20, 99-109.

Aguiar F.C. and Ferreira M.T., 2005. Human-disturbed landscapes: effects on composition and integrity of riparian woody vegetation in the Tagus river basin, Portugal. Environ. Conserv., 32, 30-41.

Aguiar M.R., Paruelo J.M., Sala O.E. and Lauenroth W.K., 1996. Ecosystem responses to changes in plant functional type composition: an example from the Patagonian steppe. J. Veg. Sci., 7, 381390.

Allred T.M. and Schmidt J.C., 1999. Channel narrowing by vertical accretion along the Green River near Green River, Utah. Geol. Soc. Am. Bull., 111, 1757-1772.

Arthington A.H., Bunn S.E., Poff N.L. and Naiman R.J., 2006. The challenge of providing environmental flow rules to sustain river ecosystems. Ecol. Appl., 16, 1311-1318.

Bejarano M.D., Nilsson C., González del Tánago M. and Marchamalo M., 2011. Responses of riparian trees and shrubs to flow regulation in a boreal stream in northern Sweden. Freshwater Biol., 56, 853-866.

Bendix J., 1998. Impact of flood on southern California riparian vegetation. Phys. Geogr., 19, $162-164$.

Birken A.S. and Cooper D.J., 2006. Processes of Tamarix invasion and floodplain development along the lower Green river. Utah. Ecol. Appl., 16, 1103-1120.

Cooper D.J., Andersen D.C. and Chimner R.A., 2003. Multiple pathways for woody plant establishment on floodplains at local to regional scale. J. Ecol., 91, 182-196.

Corenblit D., Tabacchi E., Steiger J. and Gurnell A.M., 2007. Reciprocal interactions and adjustment between fluvial landforms and vegetation dynamics in river corridors: a review of complementary approaches. Earth-Sci. Rev., 84, 56-86. 
Davies B.R., Thoms M.C., Walker K.F., O'Keeffe J.H. and Gore J.A., 1994, Dryland rivers: their ecology, conservation and management. In: Calow P. and Petts G.E. (eds.), The rivers Handbook, Blackwell Sci., 21, Oxford, 484-511.

DeWine J.M. and Cooper D.J., 2007. Effects of river regulation on riparian box elder (Acer negundo) forests in canyons of the upper Colorado river basin, USA. Wetlands, 27, 278-289.

Díaz S. and Cabido M., 1997. Plant functional types and ecosystem function in relation to global change. J. Veg. Sci., 8, 463-474.

Friedman J.M., Osterkamp W.R. and Lewis W.M., 1996. Channel narrowing and vegetation development following a Great Plains flood. Ecology, 77, 2167-2181.

Friedman J.M., Osterkamp W.R., Scott M.L. and Auble G.T., 1998. Downstream effects of dams on channel geometry and bottomland vegetation: Regional patterns in the Great Plains. Wetlands, 18, 619-633.

Gasith A. and Resh V.H., 1999. Streams in Mediterranean climate regions: abiotic influences and biotic response to predictable seasonal events. Annu. Rev. Ecol. Syst., 30, 51-81.

Hughes F.M.R., Johansson M., Xiong S., Carlborg E., Hawkins D., Svedmark M., Hayes A., Goodall A., Richards K.S. and Nilsson C., 2009. The influence of hydrological regimes on sex ratios and spatial segregation of the sexes in two dioecious riparian shrub species in northern Sweden. Plant Ecol., $208,77-92$.

Hupp C.R. and Osterkamp W.R., 1996. Riparian vegetation and fluvial geomorphic processes. Geomorphology, 14, 277-295.

Hupp C.R. and Rinaldi M., 2009. Riparian vegetation patterns in relation to fluvial landforms and channel evolution along selected rivers of Tuscany (Central Italy). Ann. Assoc. Am. Geogr., 97, 12-30.

Johnson R.R. and Lowe C.H., 1985. On the development of riparian ecology. In: Johnson R.R., Ziebell C.D., Patton D.R., Folliott P.F. and Hamre R.H. (eds.), U.S. Department of Agriculture Forest Service General Technical Report, RM-120, 112-116.

Johnson W.C., 1994. Woodland expansion in the Platte river, Nebraska: patterns and causes. Ecol. Monogr., 64, 45-84.

Johnson W.C., 1998. Adjustment of riparian vegetation to river regulation in the Great Plains, USA. Wetlands, 18, 608-618.

Johnson W.C., 2000. Tree recruitment and survival in rivers: influence of hydrological processes. Hydrol. Process., 14, 3051-3074.

Johnson W.C., Dixon M.D., Simons R., Jenson S. and Larson K., 1995. Mapping the response of riparian vegetation to possible flow reductions in the Snake river, Idaho. Geomorphology, 13, 159-173.

Malanson G.P., 1993, Riparian landscapes, Cambridge University Press, Cambridge, 299 p.

Merritt D.M. and Cooper D.J., 2000. Riparian vegetation and channel change in response to river regulation: a comparative study of regulated and unregulated streams in the Green River basin, USA. Regul. River., 16, 543-564.

Merritt D.M., Scott M.L., Poff L.N., Auble G.T. and Lytle D.A., 2010. Theory, methods and tools for determining environmental flows for riparian vegetation: riparian vegetation-flow response guilds. Freshwater Biol., 55, 206-225.

Ministerio de Medio Ambiente, 2006. Inventario de Presas Españolas, Madrid, SP.

Nadler C.T. and Schumm S.A., 1981. Metamorphosis of south platte and arkansas rivers, eastern Colorado. Phys. Geogr., 2, 95-115.

Nilsson C., 1999. Rivers and streams. Acta Phytogeogr. Suec., 84, 135-148.

Noble I.R. and Gitay H., 1996. A functional classification for predicting the dynamics of landscapes. J. Veg. Sci., 7, 329-336.

Patten D.T., 1998. Riparian ecosystems of semi-arid North America: diversity and human impacts. Wetlands, 18, 498-512.

Petts G.E., 1979. Complex response of river channel morphology subsequent to reservoir construction. Prog. Phys. Geog., 3, 329-362.

Poff N.L. and Zimmerman J.H., 2010. Ecological responses to altered flow regimes: a literature review to inform the science and management of environmental flow. Freshwater Biol., 55, 194-205.

Poff N.L., Olden J.D., Pepin D.M. and Bledsoe B.P., 2006. Placing global stream flow variability in geographic and geomorphic contexts. River Res. Appl., 22, 149-166. 
Poff N.L., Richter B.D., Arthington A.H., Bunn S.E., Naiman R.J., Kendy E., Acreman M., Apse C., Bledsoe B.P., Freeman M.C., Henriksen J., Jacobson R.B., Kennen J.G., Merritt D.M., O’Keeffe J.H., Olden J.D., Rogers K., Tharme R.E. and Warner A., 2010. The ecological limits of hydrologic alteration (ELOHA): a new framework for developing regional environmental flow standards. Freshwater Biol., 55, 147-170.

Prada M.A. and Arizpe D., 2008. Manual de propagación de árboles y arbustos de ribera, Una ayuda para la restauración de riberas en la región mediterránea, Generalitat Valenciana, Valencia, 203 p.

Resh V.H., Jackson J.K. and Mc Elravy E.P., 1990. Disturbance, annual variability, and lotic benthos: examples from a California stream influenced by a Mediterranean climate. Mem. Ist. Ital. Idrobiol., 47, 309-29.

Rosgen D., 1996. Applied river Morphology, Wildland Hydrology, Pagosa Springs, Colorado, USA.

Sabater F., Guasch H., Marti E., Armengol J. and Sabater S., 1995. The river Ter: a Mediterranean river case-study in Spain 419-38, In: Cushing C.E., Cummins K.W. and Minshall G.W. (eds.), River and Stream Ecosystems, Elsevier, Amsterdam, 817 p.

Scott M.L., Friedman J.M. and Auble G.T., 1996. Fluvial processes and the establishment of bottomland trees. Geomorphology, 14, 327-339.

Scott M.L., Auble G.T. and Friedman J.M., 1997. Flood dependency of cottonwood establishment along the Missouri river, Montana, USA. Ecol. Appl., 7, 677-690.

Shafroth P.B., Stromberg J.C. and Patten D.T., 2002. Riparian vegetation response to altered disturbance and stress regimes. Ecol. Appl., 12, 107-123.

Tabacchi E., Planty Tabacchi A.M., Salinas M.J. and Decamps H., 1996. Landscape structure and diversity in riparian plant communities: a longitudinal comparative study. Regul. Rivers, 12, 367-390.

Turner R.M. and Karpiscak M.M., 1980. Recent vegetation changes along the Colorado river between Glen Canyon Dam and Lake Mead, Arizona: USGS, Professional Paper 1132, 125 p.

Williams G.P. and Wolman M.G., 1984. Downstream effects of dams on alluvial rivers. U.S. Geol. Surv. Prof. Paper, 1286. 